\title{
Improved effect of a mitochondria-targeted antioxidant on hydrogen peroxide-induced oxidative stress in human retinal pigment epithelium cells
}

\author{
Myung Hee Kim¹, Do-Hun Kim ${ }^{1,2}$, Su Geun Yang ${ }^{1,2^{*}}$ and Dae Yu Kim ${ }^{1,3,4^{*}}$
}

\begin{abstract}
Background: Oxidative damage to retinal pigment epithelial (RPE) cells contributes to the development of agerelated macular degeneration, which is among the leading causes of visual loss in elderly people. In the present study, we evaluated the protective role of triphenylphosphonium (TPP)-Niacin against hydrogen peroxide $\left(\mathrm{H}_{2} \mathrm{O}_{2}\right)$ induced oxidative stress in RPE cells.

Methods: The cellular viability, lactate dehydrogenase release, reactive oxygen species (ROS) generation, and mitochondrial function of retinal ARPE-19 cells were determined under treatment with $\mathrm{H}_{2} \mathrm{O}_{2}$ or pre-treatment with TPP-Niacin. The expression level of mitochondrial related genes and some transcription factors were assessed using real-time polymerase chain reaction (RT-qPCR).

Results: TPP-Niacin significantly improved cell viability, reduced ROS generation, and increased the antioxidant enzymes in $\mathrm{H}_{2} \mathrm{O}_{2}$-treated ARPE-19 cells. Mitochondrial dysfunction from the $\mathrm{H}_{2} \mathrm{O}_{2}$-induced oxidative stress was also considerably diminished by TPP-Niacin treatment, along with reduction of the mitochondrial membrane potential (MMP) and upregulation of the mitochondrial-associated gene. In addition, TPP-Niacin markedly enhanced the expression of transcription factors (PGC-1 $a$ and NRF2) and antioxidant-associated genes (especially HO-1 and NQO-1).

Conclusion: We verified the protective effect of TPP-Niacin against $\mathrm{H}_{2} \mathrm{O}_{2}$-induced oxidative stress in RPE cells. TPPNiacin is believed to protect against mitochondrial dysfunction by upregulating antioxidant-related genes, such as PGC-1a, NRF2, HO-1, and NQO-1, in RPE cells.
\end{abstract}

Keywords: Age-related macular degeneration, Retinal pigment epithelium, Mitochondrial function, Antioxidants

\section{Background}

Age-related macular degeneration (AMD) is one of the most common causes of irreversible blindness in the elderly population in developed countries. There are two major forms of AMD: non-neovascular dry form of AMD affecting approximately $85-90 \%$ of patients and

\footnotetext{
* Correspondence: sugeun.yang@inha.ac.kr; dyukim@inha.ac.kr

'Inha Research Institute for Aerospace Medicine, Inha University, Incheon 22212, South Korea

Full list of author information is available at the end of the article
}

neovascular exudative wet form affecting the remaining $10-15 \%$ of patients $[1,2]$. Dry AMD (atrophy AMD) is caused by changes in the pigmentation of the retinal pigment epithelial (RPE) cells and subretinal deposits owing to lipid and protein accumulation between these cells and Bruch's membrane, a condition termed as drusen. These processes finally result in RPE cell death, photoreceptor dysfunction, and loss of vision [1-3]. At present, anti-vascular endothelial growth factor (antiVEGF) therapy has enabled extraordinary improvements

(c) The Author(s). 2021 Open Access This article is licensed under a Creative Commons Attribution 4.0 International License, which permits use, sharing, adaptation, distribution and reproduction in any medium or format, as long as you give appropriate credit to the original author(s) and the source, provide a link to the Creative Commons licence, and indicate if changes were made. The images or other third party material in this article are included in the article's Creative Commons licence, unless indicated otherwise in a credit line to the material. If material is not included in the article's Creative Commons licence and your intended use is not permitted by statutory regulation or exceeds the permitted use, you will need to obtain permission directly from the copyright holder. To view a copy of this licence, visit http://creativecommons.org/licenses/by/4.0/ The Creative Commons Public Domain Dedication waiver (http://creativecommons.org/publicdomain/zero/1.0/) applies to the data made available in this article, unless otherwise stated in a credit line to the data. 
in wet AMD; however, effective treatments for dry AMD are not yet available $[4,5]$.

Despite being a condition of unknown etiology, oxidative stress is considered as a major influence on RPE cells in AMD pathophysiology [5-7]. RPE cells have high metabolic rates with enriched mitochondrial population, and the oxidative phosphorylation process produces adenosine triphosphate (ATP), indicating the generation of high amounts of reactive oxygen species (ROS) [8]. Thus, RPE cells exist in an environment of abundant endogenous ROS, and the long-term accumulation of such oxidative damage causes dysfunctions in the RPE cells and increases their susceptibility to oxidative stress. The ROS predominantly target mitochondria and destroy their membrane integrity, dissipating the mitochondrial membrane potential $(\Delta \Psi \mathrm{m}, \mathrm{MMP})$, causing mitochondrial dysfunction, and governing cell survival. Indeed, intramitochondrial oxidative stress is connected with processes ruling cell survival, such as mitochondrial flexibility, apoptosis, and autophagy, in AMD [9]. Therefore, protecting RPE cells from oxidative damage is necessary for preventing or weakening AMD.

To improve the therapeutic effects and diminish the side effects of chemicals, researchers have investigated strategies for subcellular targeting, especially the mitochondria. The selective targeting of antioxidants toward mitochondria by covalent conjugation with the lipophilic triphenylphosphonium (TPP) cation is a popular method [10-12]. TPP, which is a well-known mitochondrial targeting moiety, is a membrane-permeant lipophilic cation that is quickly accumulated several fold within the mitochondria in vivo and is controlled by the large MMP [13]. Since the development of mitochondrial target compounds, there have been several reported mitochondria-targeting antioxidants, including MitoQ [14], MitoC [15], MitoE [16], and TPP-IOA [17]. Most of these studies employed traditional antioxidants such as vitamin $C$, vitamin $E$, and oleic acid to obtain TPP conjugates. Among these vitamins, B3 (niacin or nicotinic acid) is widely recognized as a potent antioxidant that also exerts powerful lipid-lowering effects at high concentrations [18-21]. However, based on a literature search, neither the synthesis of TPP-conjugated niacin (TPP-Niacin, Fig. 1a) for mitochondrial targeting nor its antioxidant effects have been demonstrated. Therefore, in this study, we synthesized TPP-conjugated niacin (TPP-Niacin) and investigated its protective effects on RPE cells for hydrogen peroxide $\left(\mathrm{H}_{2} \mathrm{O}_{2}\right)$-induced damage. We also evaluated the molecular actions underlying the effects of TPP-Niacin on $\mathrm{H}_{2} \mathrm{O}_{2}$-stimulated ARPE- 19 . In brief, we confirmed that TPP-Niacin exerted a protective role against $\mathrm{H}_{2} \mathrm{O}_{2}$-induced cytotoxicity and mitochondrial dysfunction via upregulation of the antioxidant-associated genes in RPE cells.

\section{Methods}

The human ARPE-19 cell line was purchased from American Type Culture Collection (ATCC, Manassas, VA, USA). Dulbecco's modified Eagle's medium: nutrient mixture F-12 media (DMEM/F12), fetal bovine serum (FBS), penicillin/streptomycin, and 2,7-dichlorofluorescein diacetate $\left(\mathrm{H}_{2} \mathrm{DCF}-\mathrm{DA}\right)$ were purchased from Thermo Fisher Scientific (Wilmington, DE, USA). Hydrogen peroxide, dihydroethidium (DHE), JC-10 assay kit, N-acetyl-cysteine (NAC), and carbonyl cyanide mchlorophenyl hydrazone (CCCP) were purchased from Sigma-Aldrich (St. Louis, MO, USA, owned by Merck KGA). TPP-Niacin was chemically synthesized according to a previous report and patent application, and niacin was used as the reference control [12, 14, 22, 23]. The Cell Counting Kit-8 (CCK-8) and lactate dehydrogenase (LDH) assays were purchased from Dojindo Molecular Technologies (Japan). The kits used to determine the superoxide dismutase 1 and 2 (SOD1 and SOD2), catalase and glutathione peroxidase activities, and tetramethylrhodamine ethyl ester (TMRE) reagent were obtained from Abcam (UK).

\section{Cell culture}

The human ARPE-19 cells were routinely maintained in DMEM/F12 supplemented with $10 \% \mathrm{FBS}$ and $1 \%$ penicillin/streptomycin. The cells were incubated at $37{ }^{\circ} \mathrm{C}$ under atmospheric conditions at $5 \% \mathrm{CO}_{2}$.

\section{Cell viability assay}

The ARPE-19 cells were placed in 96-well plates with $5 \times 10^{3}$ cells/well and incubated for $24 \mathrm{~h}$. The next day, the cells were exposed to different concentrations of TPP-Niacin for 24,48 , and $72 \mathrm{~h}$. The cell viabilities were then assessed using the CCK-8 assay. In brief, $10 \mu \mathrm{L}$ of the CCK-8 reagent was added to each sample and incubated for $1 \mathrm{~h}$. Then, the absorbance values were measured at $450 \mathrm{~nm}$ using a microplate reader (Bio-Tek, Winooski, VT, USA). To evaluate suitable $\mathrm{H}_{2} \mathrm{O}_{2}$ concentrations for oxidative damage and cytotoxic induction, the cells were seeded in 96-well plates for $24 \mathrm{~h}$ and incubated with various concentrations of $\mathrm{H}_{2} \mathrm{O}_{2}$ for another $24 \mathrm{~h}$. Then, the cell viabilities were evaluated by CCK- 8 using the same method as before. To examine the protective effects of TPP-Niacin against $\mathrm{H}_{2} \mathrm{O}_{2}$-induced oxidative damage, the seeded cells were pretreated with different concentrations of TPP-Niacin for $2 \mathrm{~h}$, followed by adding to $300 \mu \mathrm{M} \mathrm{H} \mathrm{H}_{2} \mathrm{O}_{2}$ in TPP-Niacin contained media for an additional $24 \mathrm{~h}$. Then, the cell viabilities were evaluated using CCK-8. All samples were prepared in triplicate, and each experiment was repeated three times. 
A<smiles>O=C(NCCC[PH](c1ccccc1)(c1ccccc1)c1ccccc1)c1cccnc1</smiles>

B

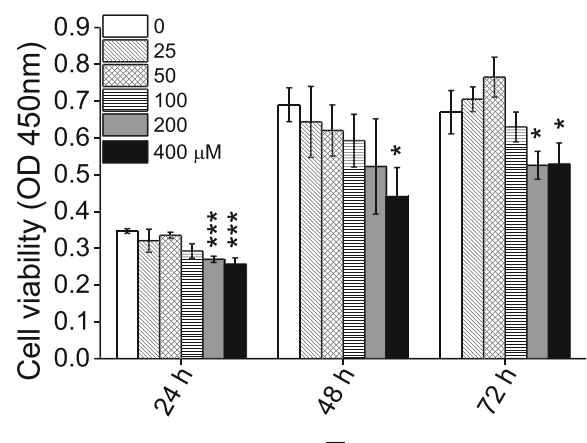

C

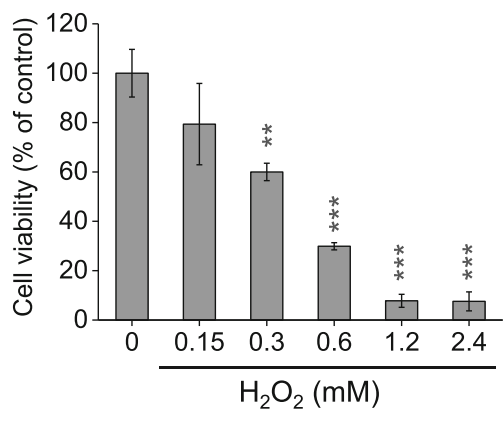

D

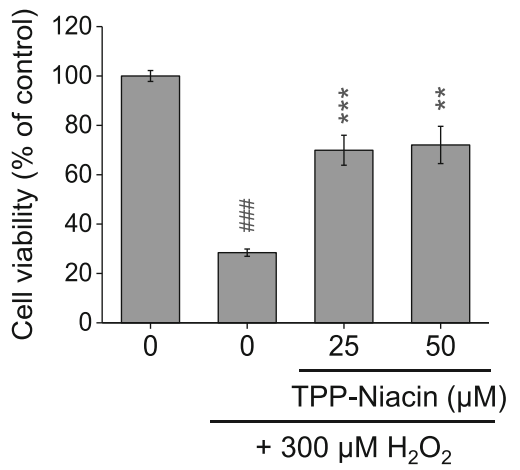

E

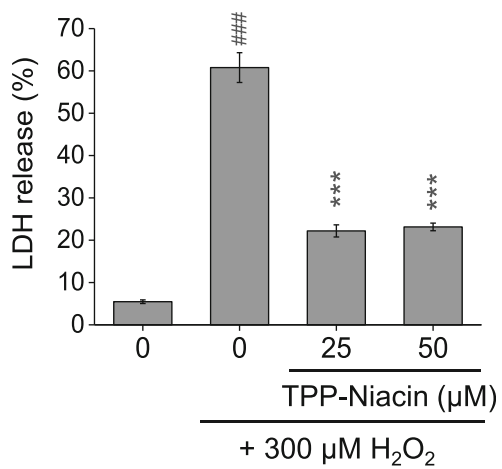

Fig. 1 Protective effects of TPP-Niacin against $\mathrm{H}_{2} \mathrm{O}_{2}$-induced cytotoxicity in ARPE-19 cells. a Chemical structure of TPP-Niacin. $\mathbf{b}$ RPE cells were treated with TPP-Niacin $(25-400 \mu \mathrm{M})$ or $0.1 \%$ DMSO (vehicle control) for $24-72 \mathrm{~h}$ and the cell viabilities were measured using the CCK-8 assay. c Cells were treated with $\mathrm{H}_{2} \mathrm{O}_{2}(0.15-2.4 \mathrm{mM})$ for $24 \mathrm{~h}$ and cell viabilities were measured. Cells were pretreated with TPP-Niacin at indicated concentrations or $0.1 \%$ DMSO (vehicle control) for $2 \mathrm{~h}$ and then incubated with or without $300 \mu \mathrm{M} \mathrm{H} \mathrm{H}_{2} \mathrm{O}_{2}$ for a further $24 \mathrm{~h}$. Cell viabilities and LDH release were measured by the CCK-8 assay $(\mathbf{d})$ and LDH assay $(\mathbf{e})$, respectively. \#\#\# $P<0.001$ versus control group and ${ }^{* *} P<0.01$, ${ }^{* * *} P<0.001$ versus the $\mathrm{H}_{2} \mathrm{O}_{2}$-treated group were considered statistically significant differences

\section{Lactate dehydrogenase (LDH) release assay}

Cell cytotoxicities were determined by the LDH released from damaged cells using the cytotoxicity LDH assay kit. In brief, ARPE-19 cells were placed in 96-well plates (5 $\times 10^{3}$ cells/well) and pretreated with different concentrations of TPP-Niacin for $2 \mathrm{~h}$, followed by adding to $300 \mu \mathrm{M} \mathrm{H} \mathrm{H}_{2} \mathrm{O}_{2}$ in TPP-Niacin contained media for $24 \mathrm{~h}$. The background of LDH in the growth medium was measured and subtracted from all test samples. The basal levels of $\mathrm{LDH}$ ( $0 \%$ cell death), as measured in the supernatants of the vehicle-treated cells, and maximal levels of LDH (100\% cell death) measured by lysis buffer induction for complete cell death, were averaged and used to calculate the percentage of cell death as per the manufacturer's protocol.

\section{Measurement of ROS}

The generation of intracellular ROS was examined using the ROS detection reagent according to manufacturer instructions. Briefly, cells were grown in a 96-well black plate (Eppendorf Ltd., Germany) and subjected to different treatments with/without TPP-Niacin and $\mathrm{H}_{2} \mathrm{O}_{2}$. Then, the cells were incubated with $5 \mu \mathrm{M} \mathrm{H}_{2} \mathrm{DCF}-\mathrm{DA}$ or $10 \mu \mathrm{M}$ DHE at $37^{\circ} \mathrm{C}$ for $20 \mathrm{~min}$. The fluorescence intensities were measured using the fluorescence plate reader (Bio-Tek) at Ex./Em. $=495 / 527 \mathrm{~nm}$ for $\mathrm{H}_{2} \mathrm{DCF}-$ $\mathrm{DA}$ and Ex./Em. $=535 / 610 \mathrm{~nm}$ for DHE. Then, the $\mathrm{H}_{2}$ DCF-DA-stained cell images were obtained with a fluorescent microscope IX51 with DP controller (Olympus Optical, Japan). All samples were prepared in triplicate, and each experiment was repeated three times.

\section{Antioxidant enzyme activity}

The ARPE-19 cells $\left(5 \times 10^{6}\right.$ cells/well $)$ were plated onto $100 \mathrm{~mm}$ cell culture dishes and pretreated with different concentrations of TPP-Niacin for $2 \mathrm{~h}$, followed by adding to $300 \mu \mathrm{M} \mathrm{H}_{2} \mathrm{O}_{2}$ in TPP-Niacin contained media for $24 \mathrm{~h}$; then, the cells were collected in clean tubes with $100 \mu \mathrm{L}$ Pro-Prep (Intron, Korea) lysis buffer for $20 \mathrm{~min}$ on ice after washing with phosphate buffered saline (PBS). Next, the supernatant was carefully collected after centrifugation and protein concentration was calculated with a bicinchoninic acid protein assay kit (Thermo Fisher Scientific). The intracellular activities of SOD1, SOD2, CAT, and GPx were detected with commercial kits (Abcam, UK) according to manufacturer directions, and the results were shown as percentages of the untreated groups. 


\section{MMP and staining}

The MMP assay was conducted as per manufacturer instructions for the JC-10 MMP assay kit. In brief, ARPE19 cells $\left(5 \times 10^{3}\right.$ cells/well $)$ seeded in the 96-well clear bottom black plates were pretreated with different concentrations of TPP-Niacin for $2 \mathrm{~h}$, followed by adding to $300 \mu \mathrm{M} \mathrm{H}_{2} \mathrm{O}_{2}$ in TPP-Niacin contained media. After 24 $\mathrm{h}$, the JC-10 assay solution was added to the cells, and the plate was incubated in the dark for $30 \mathrm{~min}$. Following incubation, the assay buffer $\mathrm{B}$ was added, and the fluorescent intensities were measured at $490 / 525 \mathrm{~nm}$ and $540 / 590 \mathrm{~nm}$ using a multimode plate reader (Bio-Tek). The ratio of red/green fluorescent intensity was used to determine the MMP. CCCP and NAC were used as the positive and antioxidant control, respectively. All samples were examined in triplicate, and each experiment was repeated three times. To visualize the effects of TPP-Niacin on the MMP, cells were stained with TMRE reagent and analyzed using an inverted fluorescence microscope IX51 with DP controller (Olympus Corporation, Japan) at Ex./Em. $=549 / 575 \mathrm{~nm}$.

\section{Transmission electron microscopy}

The treated ARPE-19 cells were washed three times with $0.1 \mathrm{M} \mathrm{PBS}$ and fixed overnight in 3\% glutaraldehyde at $4{ }^{\circ} \mathrm{C}$ and $1 \%$ osmium tetroxide solution as additional fixation for $30 \mathrm{~min}$. The cells were dehydrated with a graded series of ethanols and then embedded in epoxy resin. The embedded sample was cut into ultrathin sections around $60 \mathrm{~nm}$ using an ultramicrotome (RMC MT-XL; RMC Products, Tucson, AZ, USA) and observed with a transmission electron microscope (Hitachi H-7100, Japan).

\section{RNA collection and quantitative PCR}

The total RNA was collected using Trizol reagent (Thermo Fisher Scientific) and resuspended in RNAsefree water. The concentration of each sample was then determined using the NanoDrop 1000 spectrophotometer (Thermo Fisher Scientific). Reverse transcription was subsequently performed with $1 \mu \mathrm{g}$ of RNA to produce the complimentary DNA (cDNA) using the SensiFast cDNA synthesis kit (Bioline, London, UK). To measure the gene expression, a quantitative polymerase chain reaction (qPCR) was performed using $3 \mu \mathrm{L}$ of the cDNA template and the Power SYBR Green Master Mix (Thermo Fisher Scientific) on a StepOnePlus apparatus (Applied Systems, USA). All samples were examined in triplicate, and each experiment was repeated three times. Data were normalized to the mean expression of the housekeeping gene using GAPDH and quantified using the $2{ }^{\Delta \Delta C T}$ method. The primer sequences used are summarized in Table 1.

\section{Statistics}

Statistical analyses were performed using the GraphPad Prism 5 software (GraphPad Software Inc., La Jolla, CA, USA), and all data were presented as mean \pm SD. The Student's t-test was used to calculate statistical significance between paired groups. In this study, the statistical significances are denoted as follows: ns $\mathrm{P}>0.05, * P<$ $0.05, * * P<0.01$, and $* * P<0.001$.

\section{Results}

Cell viability and protective effect of TPP-niacin on ARPE19 cells

To evaluate the optimal concentration of TPP-Niacin (Fig. 1a) that can be used without causing cytotoxicity, the ARPE-19 cells were incubated with various concentrations of TPP-Niacin for 24, 48, and $72 \mathrm{~h}$. As shown in Fig. $1 \mathrm{~b}$, the TPP-Niacin at 25 and $50 \mu \mathrm{M}$ concentrations did not show any cytotoxicities in the ARPE-19 cells compared to the control group, whereas concentrations between 100 and $400 \mu \mathrm{M}$ attenuated the cell viabilities at 48 and $72 \mathrm{~h}$. Thus, 25 and $50 \mu \mathrm{M}$ of TPP-Niacin were used in the subsequent experiments. To determine a suitable $\mathrm{H}_{2} \mathrm{O}_{2}$ concentration for oxidative damage assessment, the cells were exposed to various concentrations of $\mathrm{H}_{2} \mathrm{O}_{2}$ for $24 \mathrm{~h}$. The $\mathrm{H}_{2} \mathrm{O}_{2}$ treatment (around $300 \mu \mathrm{M})$ significantly reduced cell viability, resulting in $46.3 \%$ cell death (Fig. 1c). Therefore, the $\mathrm{H}_{2} \mathrm{O}_{2}$ concentration of $300 \mu \mathrm{M}$ was utilized in the subsequent experiments. To test the protective effects of TPP-Niacin on $\mathrm{H}_{2} \mathrm{O}_{2}$-induced cell death, the cells were treated with TPP-Niacin for $2 \mathrm{~h}$ before being exposed to $\mathrm{H}_{2} \mathrm{O}_{2}$ for 24 h. As shown in Fig. 1d, the pretreatments with 25 and $50 \mu \mathrm{M}$ of TPP-Niacin significantly improved $\mathrm{H}_{2} \mathrm{O}_{2}$-induced reductions of ARPE- 19 cells (at $25 \mu \mathrm{M}$ : $70 \pm 6.1 \%$; at $50 \mu \mathrm{M}: 72 \pm 7.5 \%)$. The protective effects of TPPNiacin were also assessed by the LDH assay. The TPPNiacin pre-treated cells for $2 \mathrm{~h}$ significantly reduced $\mathrm{H}_{2} \mathrm{O}_{2}$-induced LDH levels (Fig. 1e). In addition, to compare the protective effects of niacin and TPP-Niacin, the cell viability assays were performed with and without oxidative stress. The test compounds did not show any cytotoxicities, and the pretreatment of cells with niacin, TPP-Niacin, and NAC for $2 \mathrm{~h}$ significantly protected the cells from $\mathrm{H}_{2} \mathrm{O}_{2}$-induced cell death (Supplementary Figure $1 \mathrm{a}$ and $1 \mathrm{~b})$.

\section{TPP-niacin suppressed $\mathrm{H}_{2} \mathrm{O}_{2}$-induced oxidative stress in ARPE- 19 cells}

The excessive accumulation of ROS is regarded as one of the main sources of cell damage induced by $\mathrm{H}_{2} \mathrm{O}_{2}$. Intracellular ROS signals were quantified using a fluorescence probe, $\mathrm{H}_{2}$ DCF-DA and DHE reagent, in the ARPE-19 cells. As shown in Fig. 2, compared with the

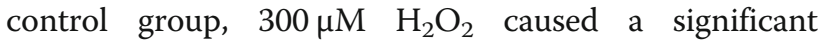


Table 1 Primer sequences used in this study

\begin{tabular}{|c|c|c|}
\hline Target gene & Forward sequence $\left(5^{\prime}-3^{\prime}\right)$ & Reverse sequence $\left(5^{\prime}-3^{\prime}\right)$ \\
\hline ATP5O & CGCTATGCCACAGCTCTTTA & $\overline{\text { AAGGCAGAAACGACTCCTTG }}$ \\
\hline COX411 & GGCATTGAAGGAGAAGGAGA & TCATGTCCAGCATCCTCTTG \\
\hline COX5B & GAGGTGGTGTTCCCACTGAT & CAGACGACGCTGGTATTGTC \\
\hline NDUFB5 & СTTCCTCACTCGTGGCTTTC & TCTGGGACATAGCCTTCTGG \\
\hline FIS1 & GACATCCGTAAAGGCATCGT & ACAGCAAGTCCGATGAGTCC \\
\hline MFN1 & TGCCCTCTTGAGAGATGACC & TCTTTCCATGTGCTGTCTGC \\
\hline MFN2 & ATGCATCCCCACTTAAGCAC & GCAGAACTITGTCCCAGAGC \\
\hline TFAM & TAAGACTGCAAGCAGCGAAG & TTCTCAGTTTCCCAGGTGCT \\
\hline POLG & TGCAGTGAGGAGGAGGAGTT & CCCAGGTAAGTGCCATGAGT \\
\hline SOD1 & GAAGGTGTGGGGAAGCATTA & CTTGCCCAAGTCATCTGCT \\
\hline SOD2 & AAACCTCAGCCCTAACGGTG & GCCTGTTGTTCCTTGCAGTG \\
\hline CAT & GATAGCCTTCGACCCAAGCA & AGAAGGCTGTTGTTCCGGAG \\
\hline GPX1 & AGTCGGTGTATGCCTTCTCG & CAAACTGGTTGCACGGGAAG \\
\hline TXN2 & TGGTGGCCTGACTGTAACAC & CACCGCTGACACCTCATACT \\
\hline PRDX3 & TGCATGTGGAAGAACGAGCT & TCCACTGAGACTGCGACAAC \\
\hline PRDX5 & AGGGTGTGCTGTTTGGAGTT & TCCACATTCAGGGCCTTCAC \\
\hline PRDX6 & CAGCTCGTGTGGTGTTTGTT & AGATGGGAGCTCTTTGGTGA \\
\hline HMOX1 & AGTCTTCGCCCCTGTCTACT & GCTTGAACTTGGTGGCACTG \\
\hline NQO1 & AAAGGACCCTTCCGGAGTAA & CGTTTCTTCCATCCTTCCAG \\
\hline PGC1a & CAAGCAAAGGGAGAGGCAGA & ACCTGCGCAAAGTGTATCCA \\
\hline PGC1b & TGGGCTGAGTTCTCCATTCT & TGAAGCTGCGATCCTTACCT \\
\hline ESRRA & TCGCTGTCTGACCAGATGTC & AGGGCCAAGGCCTITAGTAG \\
\hline FOXO1 & GCATCCATGGACAACAACAG & AGATGGCGGGTACACCATAG \\
\hline $\mathrm{FOXO3}$ & CATCATGGCAAGCACAGAGT & GAGCGTGATGTTATCCAGCA \\
\hline NRF1 & CTTACAAGGTGGGGGACAGA & CAATGTCACCACCTCCACAG \\
\hline NRF2 & GCGACGGAAAGAGTATGAGC & ACGTAGCCGAAGAAACCTCA \\
\hline PPARA & CCCTIIITGTGGCTGCTATC & ATCCGACTCCGTCTTCTTGA \\
\hline SIRT1 & CCATGGCGCTGAGGTATATT & TCTCCATCAGTCCCAAATCC \\
\hline GAPDH & ACCCAGAAGACTGTGGATGG & TTCTAGACGGCAGGTCAGGT \\
\hline
\end{tabular}

increase in the fluorescent intensity of $\mathrm{H}_{2} \mathrm{DCF}-\mathrm{DA}$ (a) and DHE (b) in the ARPE-19 cells. However, pretreatment with TPP-Niacin in the ARPE-19 cells markedly decreased the ROS levels compared to $\mathrm{H}_{2} \mathrm{O}_{2}$ treatment alone (Fig. 2a and b). The suppressive activity of TPPNiacin was also observed in the fluorescence image $\left(\mathrm{H}_{2} \mathrm{DCF}-\mathrm{DA}\right)$, as illustrated in Fig. 2c. Meanwhile, to determine the role of the antioxidant enzymes for protective effects by TPP-Niacin against oxidative damage, the expressions of major antioxidant enzymes, including SOD1, SOD2, catalase (CAT), and GPx were measured by ELISA. The pretreatment with TPP-Niacin effectively replenished the activities of SOD1 and SOD2 in the ARPE-19 cells, which were earlier decreased by treatment with $300 \mu \mathrm{M} \mathrm{H}_{2} \mathrm{O}_{2}$ (Fig. 3a and b). Additionally, the CAT activity was significantly improved by pretreatment with TPP-Niacin compared to treatment with $\mathrm{H}_{2} \mathrm{O}_{2}$ alone (Fig. 3c). As shown in Fig. 3d, pretreatment with TPP-Niacin markedly enhanced the GPx level, which was almost abrogated by treatment with $\mathrm{H}_{2} \mathrm{O}_{2}$. In addition, the ARPE-19 cells pretreated with niacin and TPP-Niacin showed marked reductions in $\mathrm{H}_{2} \mathrm{O}_{2}$-induced ROS production. As expected, TPPNiacin exerted a somewhat higher protective effect against oxidative stress compared to niacin-treated cells (as shown in Supplementary Figure 2A and 2B).

TPP-niacin decreased $\mathrm{H}_{2} \mathrm{O}_{2}$-induced change of MMP and mitochondrial morphology

Mitochondrial dysfunction causes loss of MMP $(\triangle \Psi \mathrm{m})$. To determine whether TPP-Niacin could decrease $\mathrm{H}_{2} \mathrm{O}_{2}$-induced $\Delta \Psi \mathrm{m}$ loss, the $\Delta \Psi \mathrm{m}$ of the ARPE-19 cells 


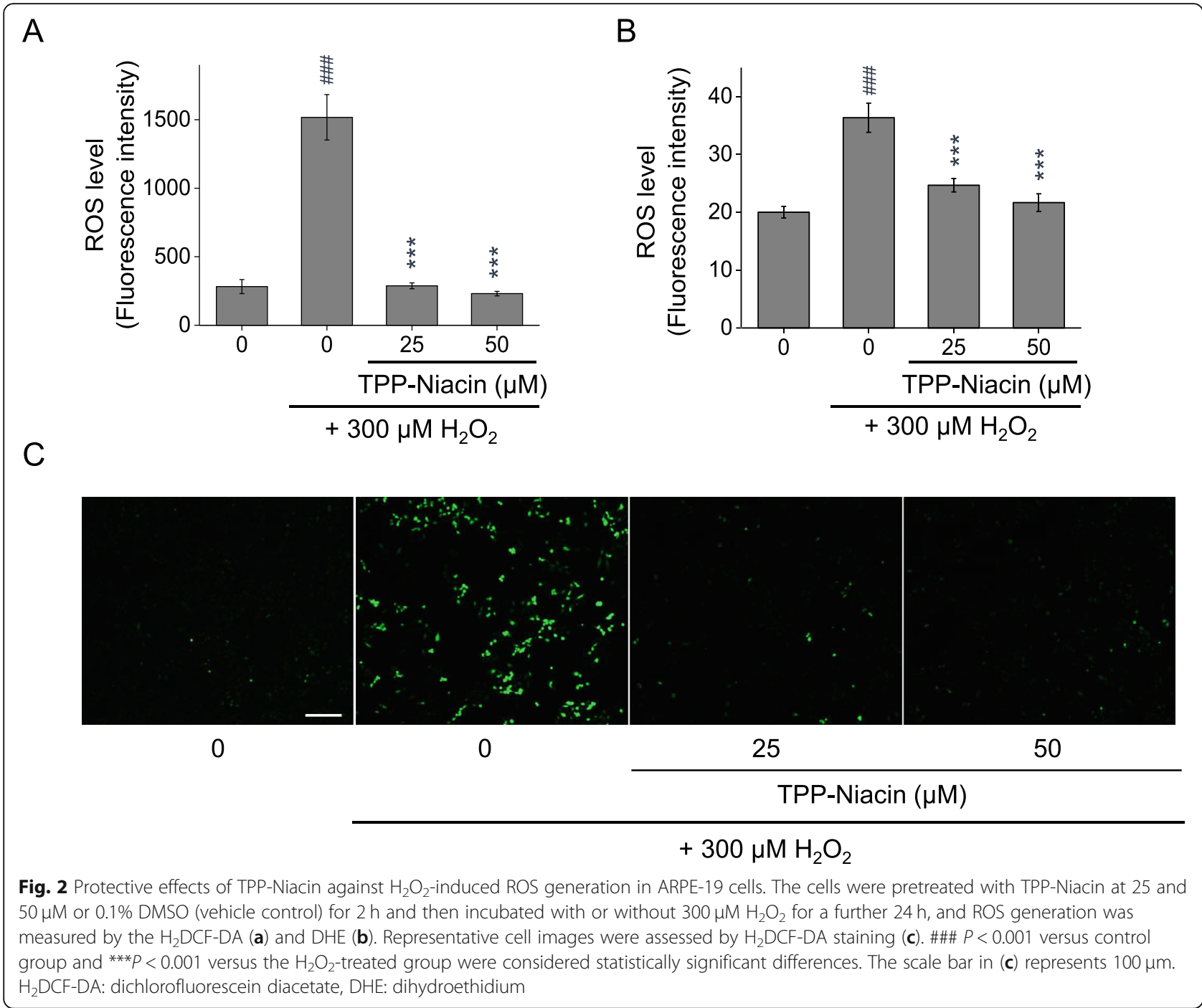

was evaluated by analyzing the red/green fluorescence intensity ratio via the JC-10 assay. As shown in Fig. 4a, the ARPE-19 cells were exposed to $300 \mu \mathrm{M} \mathrm{H}_{2} \mathrm{O}_{2}$ and resulted in decrease of red/green fluorescence intensity ratio, indicating $\triangle \Psi \mathrm{m}$ dissipation, similar to CCCP, which is a mitochondrial oxidative phosphorylation uncoupler. However, pretreatment with TPP-Niacin at 25 and $50 \mu \mathrm{M}$ for $2 \mathrm{~h}$ improved the $\mathrm{H}_{2} \mathrm{O}_{2}$-induced $\Delta \Psi \mathrm{m}$ loss to the same extent as the antioxidant positive control (NAC), as shown in Fig. 4a. The same tendency was observed in ARPE-19 cells pretreated with TPP-Niacin, when compared with those treated with $\mathrm{H}_{2} \mathrm{O}_{2}$ alone, using the TMRE reagent for visual illumination of the mitochondria (Fig. 4b). Interestingly, pretreatment with the parent compound (niacin) for $2 \mathrm{~h}$ did not show any improvement in the $\mathrm{H}_{2} \mathrm{O}_{2}$-induced $\Delta \Psi \mathrm{m}$ loss (Supplementary Figure 3); thus, the results reveal that TPPNiacin could successfully be used as a target for mitochondria. Additionally, the mitochondrial morphology was characterized by electron microscopy (EM) (Fig. 4c). The $\mathrm{H}_{2} \mathrm{O}_{2}$-treated cells showed less dense cytoplasms and larger numbers of swollen mitochondria with disrupted cristae, whereas these appeared rather uniform, including intact cristae of the mitochondria morphology, in the control group. Although some mitochondria presented a disorganized structure with disturbed cristae and swollen appearance in the TPP-Niacin pretreated cells, pretreatment with TPP-Niacin revealed diminished mitochondrial damage in the ARPE-19 cells (Fig. 4c).

\section{TPP-niacin increased expression of OXPHOS and} mitochondrial related genes

To understand the molecular mechanisms of the protective effects of TPP-Niacin on mitochondrial biogenesis, the expression of mitochondrial respiration and mitochondrial dynamics genes were studied by real-time quantitative PCR (RT-qPCR). As expected, the expressions of OXPHOS component genes, ATP synthase 


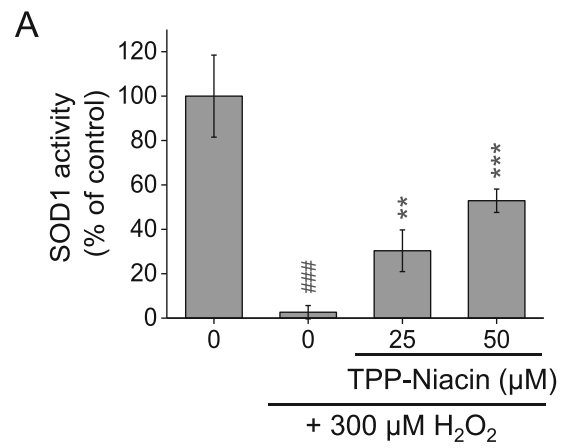

C

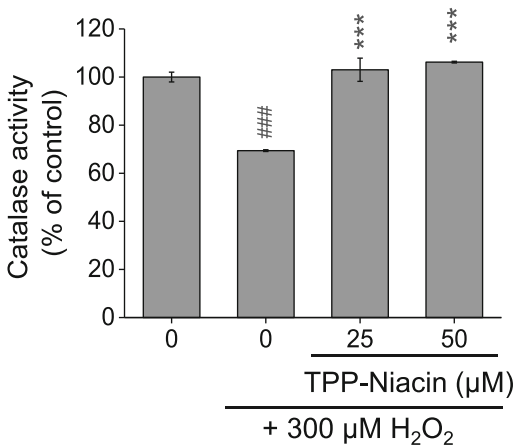

B

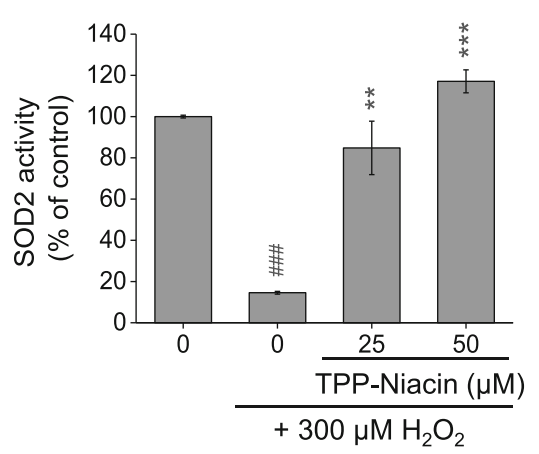

$\mathrm{D}$

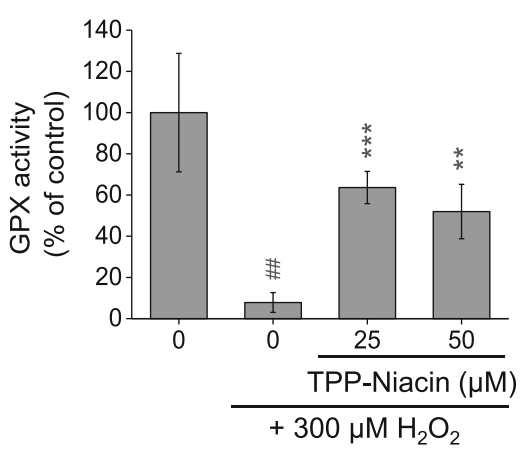

Fig. 3 TPP-Niacin improved $\mathrm{H}_{2} \mathrm{O}_{2}$-induced decreasing antioxidant status in ARPE-19 cells, which were pre-treated with TPP-Niacin at 25 and $50 \mu \mathrm{M}$ for $2 \mathrm{~h}$ and then treated with $\mathrm{H}_{2} \mathrm{O}_{2}(300 \mu \mathrm{M})$ for $24 \mathrm{~h}$. The levels of SOD1 (a), SOD2 (b) Catalase, (c) and GPx activity (d) were measured to assess the levels of antioxidant activities. \#\# $P<0.01$, \#\# $P<0.001$ versus control group and ${ }^{* *} P<0.01$, ${ }^{* *} P<0.001$ versus the $\mathrm{H}_{2} \mathrm{O}_{2}$-treated group were considered statistically significant differences. SOD1 and 2: superoxide dismutase 1 and 2, and GPx: glutathione peroxidase

subunit O (ATP5O), COX4I1 (cytochrome c oxidase subunit 4 isoform 1), cytochrome c oxidase subunit $5 \mathrm{~B}$ (COX5b), and $\mathrm{NADH}$ dehydrogenase (ubiquinone) 1 beta subcomplex, 5 (NDUFB5), were significantly increased by pretreatment with TPP-Niacin in the ARPE19 cells, as compared to $\mathrm{H}_{2} \mathrm{O}_{2}$ treatment alone and the control group (Fig. 5a). As illustrated in Fig. 5b, the mRNA expression levels of mitochondrial dynamics genes (fission 1 (FIS1), mitofusin 1 and 2 (MFN1 and 2)), mitochondrial DNA replication (polymerase (DNA directed) gamma (POLG)), and transcription gene (transcription factor a, mitochondrial (TFAM)), were significantly elevated by the TPP-Niacin compared to the $\mathrm{H}_{2} \mathrm{O}_{2}$ treated group. These results suggest that the upregulation of mitochondrial biogenesis genes intermediating the protective effect of TPP-Niacin on $\mathrm{H}_{2} \mathrm{O}_{2}$ induced cell damage in ARPE-19 cells.

\section{TPP-niacin increased expression of mitochondrial biogenesis related genes via upregulated PGC-1a/NRF2 Axis}

The transcriptional coactivator, peroxisome-proliferatoractivated receptor-gamma coactivator $1 \alpha(\mathrm{PGC}-1 \alpha)$ is a potent moderator of mitochondrial function, including oxidative phosphorylation and mitochondrial biogenesis, in RPE cells [24]. To further elucidate the involvement of PGC-1 $\alpha$ in the protective effects of TPPNiacin, the expression of PGC- $1 \alpha$ related genes and antioxidant genes were assessed by RT-qPCR. The expressions of PGC- $1 \alpha$ and PGC-1 $\beta$ were strongly upregulated after treatment with TPP-Niacin. Additionally, the gene expressions of estrogen-related receptor alpha (ESRRA), forkhead foxO1 and 3 (FOXO1, FOXO3), NRF2, PPAR $\alpha$, and Sirt1 were significantly increased by TPP-Niacin (Fig. 6a). Consistent with the results of ELISA (as shown in Fig. 3), the TPP-Niacin $(25$ and $50 \mu \mathrm{M})$ pretreatment increased the expressions of SOD1, SOD2, CAT, and GPX in ARPE-19 cells compared to the $\mathrm{H}_{2} \mathrm{O}_{2}$ treated cells. In addition, the NRF2 downstream target genes, $\mathrm{NAD}(\mathrm{P}) \mathrm{H}$ : quinone oxidoreductase 1 (NQO1), heme oxygenase-1 (HO-1), were also measured by RTqPCR. As shown in Fig. 6b, the TPP-Niacin strongly upregulated the expressions of HO-1 and NQO-1 but not that of the NOX genes (data not shown) in the $\mathrm{H}_{2} \mathrm{O}_{2}$-treated ARPE-19 cells. These results suggest that the detoxified effects of TPP-Niacin may be attributed to its action as a ROS scavenger, by which it increases the expression level of the antioxidant enzyme, via reducing oxidative damage. 


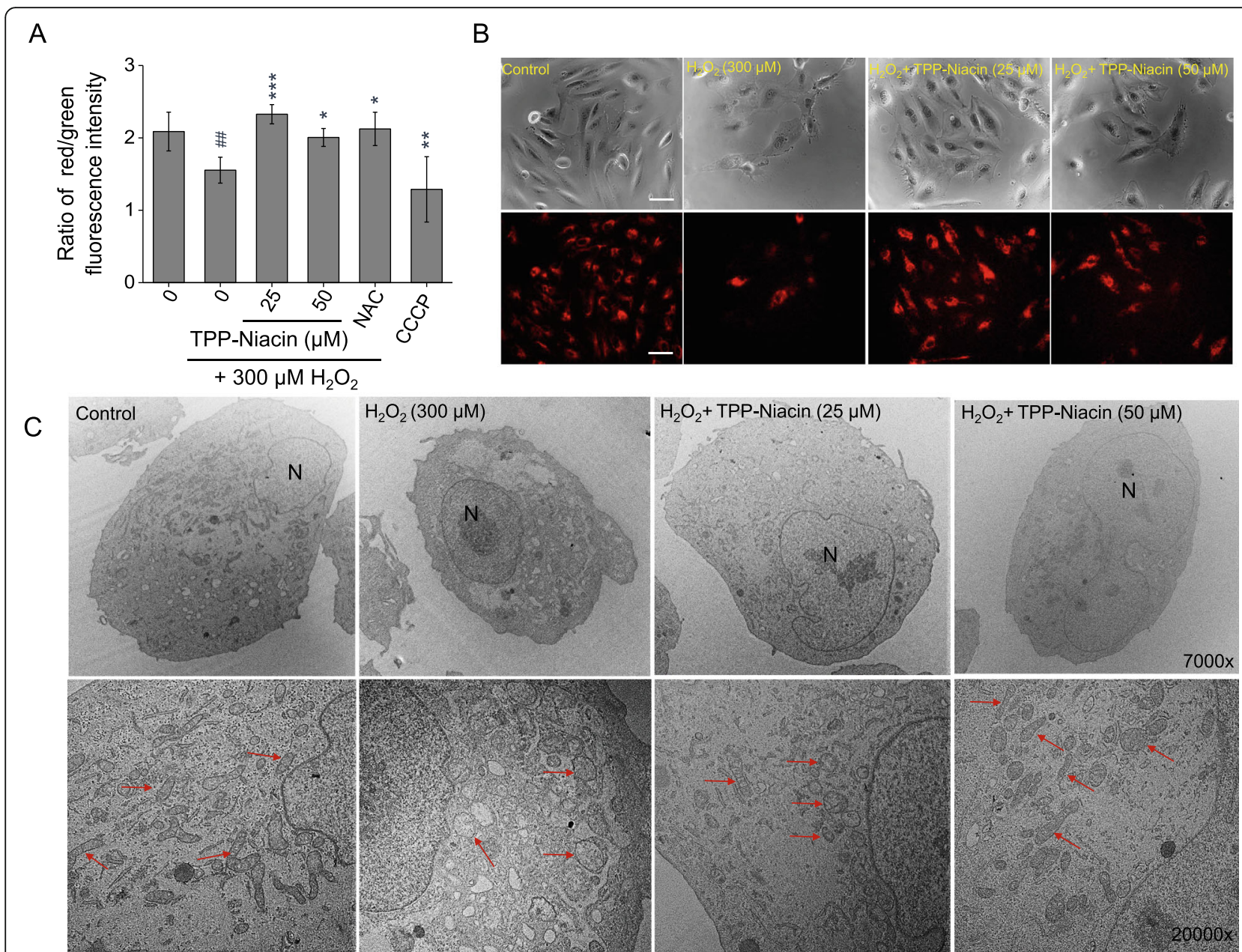

Fig. 4 TPP-Niacin attenuated $\mathrm{H}_{2} \mathrm{O}_{2}$-induced mitochondrial membrane potential $\left(\Delta \psi_{\mathrm{m}}\right)$ losses and mitochondrial morphologies of ARPE-19 cells. After pretreatment with 25 and $50 \mu \mathrm{M}$ TPP-Niacin for $2 \mathrm{~h}$, ARPE-19 cells were incubated with or without $300 \mu \mathrm{M} \mathrm{H} \mathrm{O}_{2}$ for another $24 \mathrm{~h}$. Quantification of red/green fluorescence intensities was determined by the JC-10 assay (a) and $\Delta \psi \mathrm{m}$ was determined by TMRE staining. $\mathbf{b}$ CCCP $(40 \mu \mathrm{M})$ and NAC $(4 \mathrm{mM})$ were used as the positive and antioxidant controls, respectively. c Representative electron microscope images of the mitochondrial shape in the ARPE-19 cells treated without $\mathrm{H}_{2} \mathrm{O}_{2}$, with $300 \mu \mathrm{M} \mathrm{H}_{2} \mathrm{O}_{2}$ alone or with $300 \mu \mathrm{M} \mathrm{H} \mathrm{O}_{2}$ and 25 or $50 \mu \mathrm{M}$ TPP-Niacin for 24 h. \#\# $\mathrm{P}<0.01$ versus control group and ${ }^{*} P<0.05$, ${ }^{*} P<0.01$, ${ }^{* *} P<0.001$ versus the $\mathrm{H}_{2} \mathrm{O}_{2}$-treated group were considered statistically significantly different. Scale bar represents $50 \mu \mathrm{m}$. TMRE: tetramethylrhodamine ethyl ester, CCCP: carbonyl cyanide m-chlorophenyl hydrazine,

NAC: N-acetyl-cysteine

\section{Discussion}

Oxidative stress in the retina plays a major role in the pathogenesis of dry AMD. While antioxidant defense systems in the retinal cells are appropriate under normal states, strong oxidative stress disintegrates the normal antioxidant systems and result in irreparable damage to the retina. It has been reported that the use of additional antioxidants reduces oxidative stress and preserves retinal function while avoiding oxidative damage $[25,26]$. In addition, experimental and clinical studies suggest that consuming high doses of antioxidants, such as lutein, $\beta$-carotene, vitamins, and zinc supplements, possibly protect against and curtail the progression of AMD and vision loss [2]. In the present study, we demonstrated the improved protective effects of TPPNiacin, a mitochondrial targeting compound, for the first time against oxidative damage in human RPE cells. At the mitochondrial level, the TPP-Niacin exerts improved protective effects via mediation of the MMP and its related effector genes, including OXPHOS, mitochondrial dynamics, and mitochondrial DNA replication and transcription. Notably, TPP-Niacin is capable of prevention against oxidative damage by incrementing the expression levels of antioxidant enzymes, mainly HO-1 and NQO-1, via upregulation of PGC- $1 \alpha$ and NRF2 in the ARPE-19 cells. Furthermore, TPP-Niacin provides better protection than niacin against oxidative damage in ARPE-19 cells, therefore underscoring the potential use of TPP- 

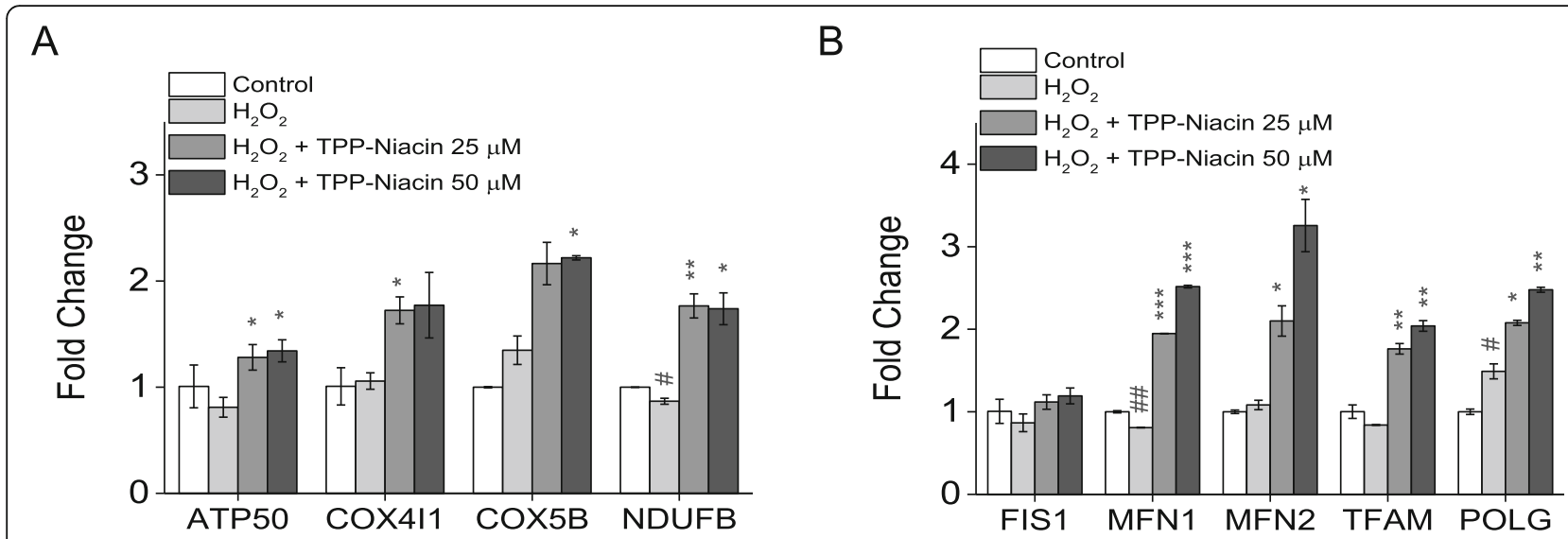

Fig. 5 TPP-Niacin upregulated expression of OXPHOS target genes and mitochondrial dynamics genes in ARPE-19 cells. Relative expression of OXPHOS genes (a) and mitochondrial dynamic genes (FIS1, MFN1, and MFN2) and replication genes (TFAM and POLG) (b) in ARPE-19 treated for $2 \mathrm{~h}$ with 25 or $50 \mu \mathrm{M}$ TPP-Niacin and then incubated with or without $300 \mu \mathrm{M} \mathrm{H}_{2} \mathrm{O}_{2}$ for a further $24 \mathrm{~h}$. \# $P<0.05$, \#\# $P<0.01$ versus control group and ${ }^{*} P<0.05$, ${ }^{*} P<0.01$, ${ }^{* *} P<0.001$ versus the $\mathrm{H}_{2} \mathrm{O}_{2}$-treated group were considered statistically significantly different

Niacin as a possible therapeutic agent for AMD, a disease that initiated by cell death from oxidative stress and RPE dysfunction.

RPE cells are one of the types of cells that consume high amounts of energy, exist in the back of the photoreceptor cells, and have the most commonplace oxidative-damaged compositions in the retina. $\mathrm{H}_{2} \mathrm{O}_{2}$ is a critical factor in producing oxidative damage and cell deaths in various cell types, including retinal cells [27]. In the present study, $\mathrm{H}_{2} \mathrm{O}_{2}$ was used to test ARPE-19 cells to generate oxidative stress and cell cytotoxicity to imitate the onset of dry AMD. As noted in the viabilities and LDH assays, pretreatment with TPP-Niacin in the ARPE-19 cells significantly increased the cell viability against $\mathrm{H}_{2} \mathrm{O}_{2}$-induced cell death, whereas TPP-Niacin reduced cell death by oxidative damage. Intriguingly, TPP-Niacin treatment alone was able to slightly increase the growth of the ARPE-19 cells compared to the parent compound (Supplementary Figure 1a).

Intracellular accumulation of ROS is related with oxidative stress and dysfunction of RPE cells [28]. Reduction of intracellular ROS may protect the RPE cells from oxidative damage $[5,29]$. The results of this study confirmed that TPP-Niacin markedly diminished $\mathrm{H}_{2} \mathrm{O}_{2}$-induced intracellular ROS levels in RPE cells, as observed via $\mathrm{H}_{2}$ DCF-DA and DHE staining. Major antioxidant enzymes exist, including $\mathrm{Cu} / \mathrm{Zn}$-superoxide dismutase (cytosolic SOD, SOD1), manganese superoxide dismutase (mitochondrial SOD, SOD2), catalase, and glutathione peroxidase (GPx). The SOD converts superoxide to oxygen and hydrogen peroxide, whereas catalase and GPx transform hydrogen peroxide into $\mathrm{H}_{2} \mathrm{O}$ and $\mathrm{O}_{2}$ [28, 29]. The present study demonstrated that pre-incubation with TPP-Niacin increased SOD1 and SOD2 compared to the $\mathrm{H}_{2} \mathrm{O}_{2}$ group, thus suggesting that TPP-Niacin could combat oxidative stress. Additionally, the TPPNiacin significantly increased catalase and GPx activities that were decreased by $\mathrm{H}_{2} \mathrm{O}_{2}$ in the ARPE- 19 cells. These data indicate that TPP-Niacin may retain the ability to indirectly scavenge oxygen free radicals. Consequently, TPP-Niacin may reduce $\mathrm{H}_{2} \mathrm{O}_{2}$-induced oxidative stress in ARPE-19 cells by decreasing the intracellular ROS status and by eliminating oxygen free radicals. In addition, we observed that ARPE-19 cells pretreated with niacin and TPP-Niacin markedly reduced the $\mathrm{H}_{2} \mathrm{O}_{2}$-induced ROS production. As expected, the TPP-Niacin exerted a somewhat higher preventive effect against oxidative damage, as shown by a $10 \%$ increment in cell viability and $17 \%$ decrement in ROS level compared to niacin-treated cells, respectively. The antioxidant activities of TPP-Niacin are at a slightly higher level compared to the parent compound, suggesting that the mitochondria-targeting TPP-Niacin is an effective derivative of the parent compound.

The pathological changes of mitochondrial-related dysfunctions, including accumulation of ROS and superoxide in the mitochondria and MMP $(\triangle \Psi \mathrm{m})$ reduction, were discovered in AMD [25]. In other mitochondrial targeting compounds $[10,14,30]$, we observed that pretreatment with TPP-Niacin significantly enhanced the MMP and improved the mitochondrial ultrastructure in a phenotypic analysis by EM, compared to $\mathrm{H}_{2} \mathrm{O}_{2}$ alone. Based on these data, we next analyzed the expressions of mitochondria-related genes, such as OXPHOS subunits, mitochondrial dynamics, and mitochondrial DNA replication and transcription genes. Our results showed that TPP-Niacin significantly upregulated COX4I1, COX5B, NDUFB as well as MFN1, MFN2, TFAM, and POLG 
A

B
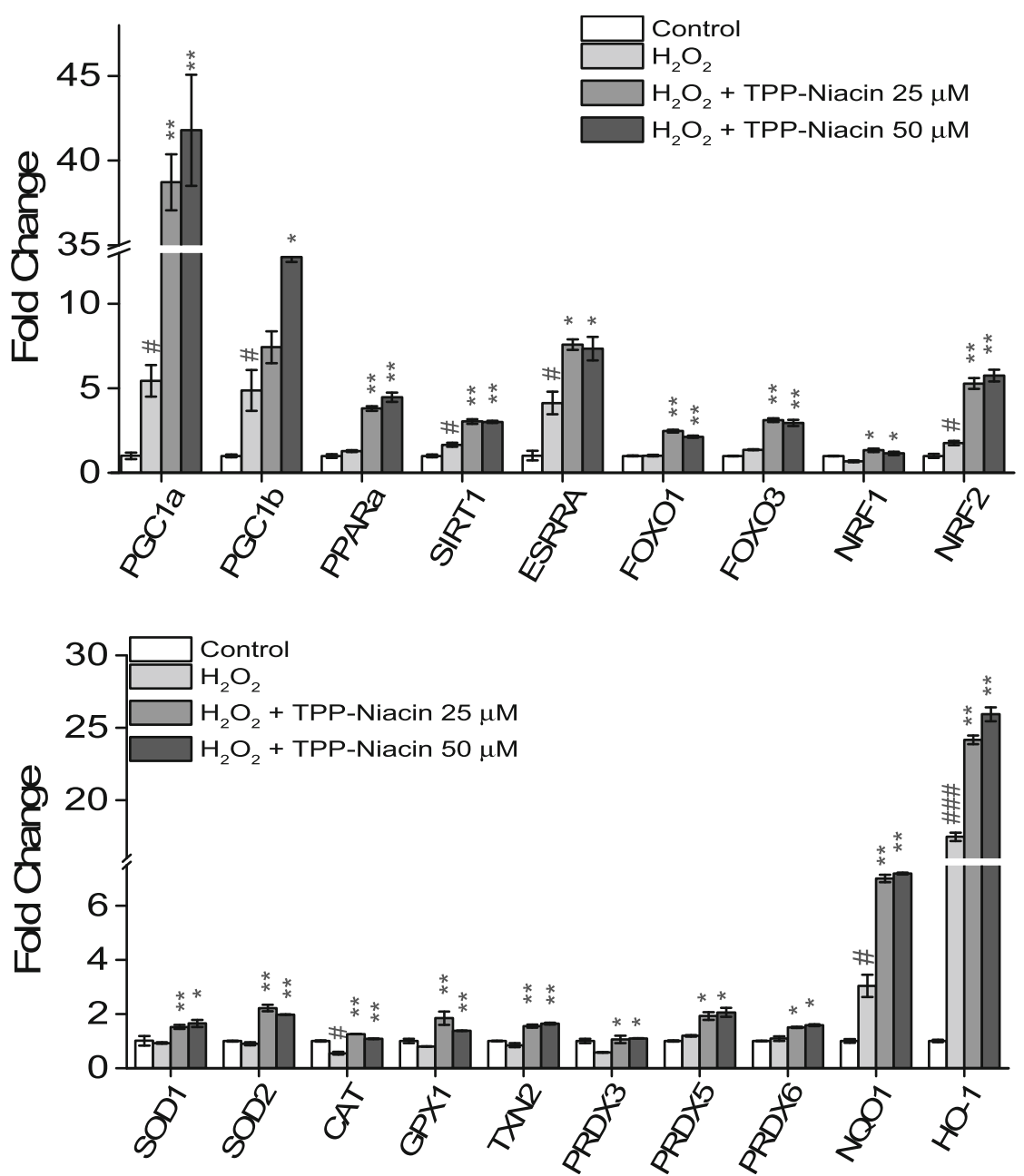

Fig. 6 Involvement of PGC-1a/NRF2/NQO1/HO-1 axis for antioxidant effects of TPP-Niacin. Gene expression analysis by qPCR of transcription factors (a) and major antioxidant related genes (b). All gene expression data were analyzed using Student's t-test. Statistical significance is represented as follows: \# $P<0.05$, \#\#\# $P<0.01$ versus control group; $* P<0.05, * * P<0.01$, and $* * * P<0.001$ versus the $\mathrm{H}_{2} \mathrm{O}_{2}$-treated group

genes; thus, these mitochondrial specific effects of TPPNiacin could lead to improved mitochondrial function and biogenesis against oxidative stress by $\mathrm{H}_{2} \mathrm{O}_{2}$.

Peroxisome proliferator-activated receptor gamma coactivator 1-alpha (PGC-1 $\alpha)$ and -beta (PGC-1 $\beta)$ are transcriptional coactivators that control mitochondrial metabolism and functions in various tissues [31], including the retina [27, 32, 33]. To intermediate their functions, the PGC- $1 \alpha$ isoforms cooperate with transcription factors, such as ESRRA, peroxisome proliferatoractivated receptor $\alpha, \gamma($ PPAR $\alpha, \gamma)$, FOXO1, FOXO3, and nuclear respiratory factors 1 (NRF1) and Nfe212 (nuclear factor erythroid 2-related factor 2, NRF2) to control respiration, mitochondrial biogenesis, and expression of antioxidants $[27,34]$. PGC- $1 \alpha$ is necessary for the generation of ROS scavenging enzymes, including SOD1, SOD2, GPx, and CAT $[35,36]$. Recently, several studies have shown that superoxide dismutase 2 (SOD2), an enzyme detoxifying the excessive accumulation of mitochondrial ROS, was turned on by PGC- $1 \alpha$ in the RPE cells [27, 37]. Therefore, to determine the possible pathways of protective effects of the TPP-Niacin, we examined the gene expressions of PGC- $1 \alpha$ related genes and observed that PGC- $1 \alpha$ and PGC- $1 \beta$ were robustly upregulated by TPP-Niacin compared to the $\mathrm{H}_{2} \mathrm{O}_{2}$-induced oxidative damage group. In addition, when examining the potential downstream transcription factors responsible for these changes, ESRRA, FOXO1 and 3, and NRF1 and 2 were found to be upregulated by TPPNiacin treatment.

On further investigating the possible mechanisms associated with the protective ability of TPP-Niacin, it appears that HO-1 and NQO-1, which are downstream targets of NRF2 signaling, play major roles in the 
prevention of oxidative damage in the cells $[38,39]$. Recently, many studies have reported that the activation of NRF2/HO-1 signaling is required to alleviate oxidative damages in RPE cells [40-45]. In this study, it was speculated that the antioxidative effects of TPP-Niacin could be combined with PGC- $1 \alpha$ and NRF2 signaling. The results of the present study show that TPP-Niacin protects the ARPE- 19 cells from $\mathrm{H}_{2} \mathrm{O}_{2}$-induced oxidative damage by activating NRF2 signaling through upregulation of the expression of NRF2, NQO-1, and HO-1.

Initially, we thought that TPP-Niacin had an effect on the nanoconcentration state, as well as those of other mitochondrial targeting compounds, but TPP-Niacin showed antioxidant effects in the range of $10-200 \mu \mathrm{M}$. However, as shown in the comparison data with niacin, TPP-Niacin is more effective than its original chemical against oxidative damage in RPE cells. These results support TPP-Niacin as a potent antioxidant against oxidative stress compared to niacin and suggest that its improved protective effects are exerted via regulation of mitochondrial dynamics and antioxidant mechanisms. Contrary to expectations, the increment of antioxidant enzymes after induction of oxidative stress was in agreement with the study where the expression levels of $\mathrm{HO}$ 1 increased in ARPE-19 cells after $\mathrm{H}_{2} \mathrm{O}_{2}$ treatment [43, 44, 46-48]. However, some studies have presented that $\mathrm{H}_{2} \mathrm{O}_{2}$ treatment significantly reduces the expression levels of PGC-1 $\alpha, \mathrm{HO}-1$, and NQO-1 in ARPE-19 cells $[37,40]$. The variances between these studies may be owed to the use of other concentrations of stimuli as well as the treatment time, which can control cellular response. As in reported research, it is well established that niacin exerts significant antioxidant, antiinflammatory and anti-apoptotic activities in a variety of cells and tissues [19, 20, 49-52]. Our study thus far has only been applied to focus upon the improved antioxidant effects of TPP-Niacin, in terms of mitochondrial and ROS regulation. Further data collection would be needed to determine exactly how TPP-Niacin affects with antioxidant effect via mitochondrial biogenesis and dynamics. Additionally, when we exam the TPP-Niacin's own effects on normal ARPE-19 cells, as shown in Supplementary Figure 4, TPP-Niacin was not significantly changed of ARPE-19 cells compared with the control group in LDH, ROS, and MMP assay (Supplementary Figure $4 \mathrm{a}$-d). However, according to gene expression results, TPP-Niacin has significantly enhanced the SOD2 expression level assessed by RT-qPCR (Supplementary Figure 4e). These results indicated that TPP-Niacin mediated cytoprotective activities that could be linked to the mitochondrial function on not only the normal state but also the oxidative stress.

In conclusion, this study shows that TPP-Niacin is an improved protective antioxidant than niacin against oxidative damage to ARPE-19, cells via the reduction of ROS levels and protection against oxidative-stressinduced cell death. The signal mechanisms by which TPP-Niacin presented such effects involve regulation of the mitochondrial quality control and transcriptional factors such as PGC-1 $\alpha$ and NRF2, as well as a boost in the antioxidant molecules. These results provide the first experimental evidence for TPP-Niacin as a possible therapeutic agent in the prevention of AMD. Further studies are needed to determine its physiological functions and biological efficacies in both primary human RPE cells (at least fully differentiated ARPE-19 cell models) and in vivo models, as well as target identification in the near future.

\section{Supplementary Information}

The online version contains supplementary material available at https://doi. org/10.1186/s40360-020-00471-w.

Additional file 1. Comparison data between niacin and TPP-Niacin for this study can be found in the additional supplementary materials.

\begin{abstract}
Abbreviations
AMD: Age-related macular degeneration; RPE: Retinal pigment epithelium; TPP: Triphenylphosphonium; ROS: Reactive oxygen species; VEGF: Vascular endothelial growth factor; LDH: Lactate dehydrogenase; MMP: Mitochondrial membrane potential; NAC: N-acetyl-cysteine; CCCP: Carbonyl cyanide mchlorophenyl hydrazone; $\mathrm{H}_{2}$ DCF-DA: 2,7-dichlorofluorescein diacetate; DHE: Dihydroethidium; TMRE: Tetramethylrhodamine, ethyl ester; SOD1 and SOD2: Superoxide dismutase 1 and 2; CAT: Catalase; GPx: Glutathione peroxidase; EM: Electron microscopy; OXPHOS: Oxidative phosphorylation; ATP5O: ATP synthase subunit O; COX411: Cytochrome c oxidase subunit 4 isoform 1; COX5b: Cytochrome c oxidase subunit 5B; NDUFB5: NADH dehydrogenase (ubiquinone) 1 beta subcomplex, 5; FIS1: Fission 1; MFN1 and 2: Mitofusin 1 and 2; POLG: Mitochondrial DNA replication (polymerase (DNA directed), gamma; TFAM: Transcription factor a, mitochondrial; PGC1a: Peroxisome-proliferator-activated receptor-gamma coactivator 1a; ESRRA: Estrogen-related receptor alpha; PPARa, $\gamma$ : Peroxisome proliferator-

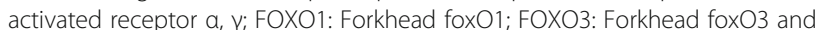
NRF1 nuclear respiratory factors 1; NRF2: Nfe212 (nuclear factor erythroid 2related factor 2; HO-1: Heme oxygenase-1; NQO-1: NAD(P)H: quinone oxidoreductase 1; NOX: NADPH oxidase
\end{abstract}

\section{Acknowledgments \\ Not applicable.}

\section{Authors' contributions}

M.H.K. and S.G. Y. conceptualization of the study; M.H.K. and D.H. K. performed the experiments; M.H.K. analyzed the data; M.H.K. wrote the paper; D.Y.K. and S.G.Y. reviewed and edited the manuscript. The author(s) read and approved the final manuscript.

\section{Funding}

The work was supported by the Ministry of Education National Research Foundation (NRF) through the Basic Science Research Program under Grant NRF-2017R1D1A1B03030396 and 2018R1A6A1A03025523 and was partially supported by the Bio \& Medical Technology Development Program of the National Research Foundation (NRF) \& funded by the Ministry of Science \& ICT (2019M3E5D1A02069623).

\section{Availability of data and materials}

The datasets used and analyzed during the current study are available from the corresponding author on reasonable request. 


\section{Ethics approval and consent to participate}

Not applicable.

\section{Consent for publication}

Not applicable.

\section{Competing interests}

The authors declare that they have no competing interests.

\section{Author details \\ 'Inha Research Institute for Aerospace Medicine, Inha University, Incheon 22212, South Korea. ${ }^{2}$ Department of Biomedical Science, BK21 FOUR Program in Biomedical Science \& Engineering, Inha University College of Medicine, Incheon 22332, South Korea. ${ }^{3}$ Department of Electrical Engineering, College of Engineering, Inha University, Incheon 22212, South Korea. ${ }^{4}$ Center for Sensor Systems, Inha University, Incheon 22212, South Korea.}

Received: 21 June 2020 Accepted: 27 December 2020

Published online: 20 January 2021

\section{References}

1. Miller JW, Bagheri S, Vavvas DG. Advances in Age-related Macular Degeneration Understanding and Therapy. US Ophthalmic Rev. 2017;10:119.

2. Holz FG, Schmitz-Valckenberg S. Fleckenstein M. Recent developments in the treatment of age-related macular degeneration. J Clin Invest. 2014;124: 1430-8. https://doi.org/10.1172/JC171029.

3. Bowes Rickman C, Farsiu S, Toth CA, Klingeborn M. Dry age-related macular degeneration: Mechanisms, therapeutic targets. and imaging. Investig Ophthalmol Vis Sci. 2013;54:ORSF68.

4. Nebbioso M, Lambiase A, Cerini A, Limoli PG, La Cava M, Greco A. Therapeutic Approaches with Intravitreal Injections in Geographic Atrophy Secondary to Age-Related Macular Degeneration: Current Drugs and Potential Molecules. Int J Mol Sci. 2019;20:1693. https://doi.org/10.3390/ ijms20071693.

5. Hernández-Zimbrón LF, Zamora-Alvarado R, Ochoa-De la Paz L, VelezMontoya R, Zenteno E, Gulias-Cañizo R, et al. Age-Related Macular Degeneration: New Paradigms for Treatment and Management of AMD. Oxid Med Cell Longev. 2018;2018:1-14.

6. Hollyfield JG, Bonilha VL, Rayborn ME, Yang X, Shadrach KG, Lu L, et al. Oxidative damage-induced inflammation initiates age-related macular degeneration. Nat Med. 2008;14:194-8. https://doi.org/10.1038/nm1709.

7. Shaw PX, Stiles T, Douglas C, Ho D, Fan W, Du H, et al. Oxidative stress, innate immunity, and age-related macular degeneration. AIMS Mol Sci. 2016;3:196-221. https://doi.org/10.3934/molsci.2016.2.196.

8. Murphy MP. How mitochondria produce reactive oxygen species. Biochem J. 2009:417:1-13. https://doi.org/10.1042/BJ20081386.

9. Hyttinen JMT, Viri J, Kaarniranta K, Błasiak J. Mitochondrial quality control in AMD: does mitophagy play a pivotal role? Cell Mol Life Sci. 2018;75:29913008. https://doi.org/10.1007/s00018-018-2843-7.

10. Smith RAJ, Hartley RC, Cochemé HM, Murphy MP. Mitochondrial pharmacology. Trends Pharmacol Sci. 2012;33:341-52. https://doi.org/10. 1016/j.tips.2012.03.010.

11. Logan A, Murphy MP. Using chemical biology to assess and modulate mitochondria: Progress and challenges. Interface Focus. 2017;7:20160151.

12. Battogtokh G, Choi YS, Kang DS, Park SJ, Shim MS, Huh KM, et al. Mitochondria-targeting drug conjugates for cytotoxic, anti-oxidizing and sensing purposes: current strategies and future perspectives. Acta Pharm Sin B. 2018;8:862-80. https://doi.org/10.1016/j.apsb.2018.05.006.

13. Murphy MP. Understanding and preventing mitochondrial oxidative damage. Biochem Soc Trans. 2016;44:1219-26. https://doi.org/10.1042/ BST20160108

14. Kelso GF, Porteous CM, Coulter CV, Hughes G, Porteous WK, Ledgerwood EC, et al. Selective targeting of a redox-active ubiquinone to mitochondria within cells: antioxidant and antiapoptotic properties. J Biol Chem. 2001;276 4588-96. https://doi.org/10.1074/jbc.M009093200.

15. Finichiu PG, Larsen DS, Evans C, Larsen L, Bright TP, Robb EL, et al. A mitochondria-targeted derivative of ascorbate: MitoC. Free Radic Biol Med. 2015;89:668-78.
16. Jameson VJA, Cochemé HM, Logan A, Hanton LR, Smith RAJ, Murphy MP. Synthesis of triphenylphosphonium vitamin E derivatives as mitochondriatargeted antioxidants. Tetrahedron. 2015;71:8444-53. https://doi.org/10. 1016/j.tet.2015.09.014.

17. Maddalena LA, Ghelfi M, Atkinson J, Stuart JA. The mitochondria-targeted imidazole substituted oleic acid "TPP-IOA" affects mitochondrial bioenergetics and its protective efficacy in cells is influenced by cellular dependence on aerobic metabolism. Biochim Biophys Acta - Bioenerg. 2017:1858:73-85.

18. Boden WE, Sidhu MS, Toth PP. The Therapeutic Role of Niacin in Dyslipidemia Management. J Cardiovasc Pharmacol Ther. 2014;19:141-58. https://doi.org/10.1177/1074248413514481.

19. Si Y, Zhang Y, Zhao J, Guo S, Zhai L, Yao S, Sang H, Yang N, Song G, Gu J, Qin S. Niacin inhibits vascular inflammation via downregulating nuclear transcription factor-KB signaling pathway. Mediators Inflamm. 2014;2014 263786. https://doi.org/10.1155/2014/263786.

20. Ganji SH, Qin S, Zhang L, Kamanna VS, Kashyap ML. Niacin inhibits vascular oxidative stress, redox-sensitive genes, and monocyte adhesion to human aortic endothelial cells. Atherosclerosis. 2009;202:68-75. https://doi.org/10. 1016/j.atherosclerosis.2008.04.044.

21. Kamanna VS, Kashyap ML. Mechanism of Action of Niacin. Am J Cardiol. 2008;101:S20-6. https://doi.org/10.1016/J.AMJCARD.2008.02.029.

22. Yuan $\mathrm{H}$, Cho $\mathrm{H}$, Chen $\mathrm{HH}$, Panagia M, Sosnovik DE, Josephson L. Fluorescent and radiolabeled triphenylphosphonium probes for imaging mitochondria. Chem Commun. 2013:49:10361-3.

23. Yang SG, Kim DH. South Korea Patent Application No. 10--2019-0075016; 2019.

24. lacovelli J, Rowe GC, Khadka A, Diaz-Aguilar D, Spencer C, Arany Z, et al. PGC-1a induces human RPE oxidative metabolism and antioxidant capacity. Investig Ophthalmol Vis Sci. 2016;57:1038-51.

25. SanGiovanni JP, Chew EY, Clemons TE, Ferris FL, Gensler G, Lindblad AS, et al. The relationship of dietary carotenoid and vitamin $A, E$, and $C$ intake with age-related macular degeneration in a case-control study: AREDS report No. 22. Arch Ophthalmol. 2007;125:1225-32.

26. Richer S, Patel S, Sockanathan S, Ulanski LJ, Miller L, Podella C. Resveratrol based oral nutritional supplement produces long-term beneficial effects on structure and visual function in human patients. Nutrients. 2014;6:4404-20.

27. Cai J, Nelson KC, Wu M, Sternberg P, Jones DP. Oxidative damage and protection of the RPE. Prog Retin Eye Res. 2000;19:205-21. https://doi.org/ 10.1016/S1350-9462(99)00009-9.

28. Babizhayev MA, Yegorov YE. Reactive Oxygen Species and the Aging Eye. Am J Ther. 2016;23:e98-117. https://doi.org/10.1097/MJT.0b013e3181ea31ff.

29. Nita M, Grzybowski A. The Role of the Reactive Oxygen Species and Oxidative Stress in the Pathomechanism of the Age-Related Ocular Diseases and Other Pathologies of the Anterior and Posterior Eye Segments in Adults. Oxid Med Cell Longev. 2016;2016:3164734.

30. Zernii EY, Gancharova OS, Baksheeva VE, Golovastova MO, Kabanova El, Savchenko MS, et al. Mitochondria-targeted antioxidant SkQ1 prevents anesthesia-induced dry eye syndrome. Oxid Med Cell Longev. 2017;2017: 9281519.

31. Finck BN, Kelly DP, Finck BN, Kelly DP. PGC-1 coactivators : inducible regulators of energy metabolism in health and disease Find the latest version : Review series PGC-1 coactivators: inducible regulators of energy metabolism in health and disease. J Clin Investig. 2006:116:615-22

32. Saint-Geniez M, Jiang A, Abend S, Liu L, Sweigard H, Connor KM, et al. PGCla regulates normal and pathological angiogenesis in the retina. Am J Pathol. 2013;182:255-65. https://doi.org/10.1016/j.ajpath.2012.09.003.

33. Guo X, Dason ES, Zanon-Moreno V, Jiang Q, Nahirnyj A, JGF DC, MS J. PGC1a Signaling Coordinates Susceptibility to Metabolic and Oxidative Injury in the Inner Retina. Am J Pathol. 2014;184(4):1017-29. https://doi.org/10.1016/j. ajpath.2013.12.012.

34. Kaarniranta K, Pawlowska E, Szczepanska J, Jablkowska A, Blasiak J, Kaarniranta K, et al. Role of Mitochondrial DNA Damage in ROS-Mediated Pathogenesis of Age-Related Macular Degeneration (AMD). Int J Mol Sci. 2019;20:2374. https://doi.org/10.3390/ijms20102374.

35. Austin S, St-Pierre J. PGC1a and mitochondrial metabolism-emerging concepts and relevance in ageing and neurodegenerative disorders. J Cell Sci. 2012;125:4963-71. https://doi.org/10.1242/jcs.113662.

36. St-Pierre J, Drori S, Uldry M, Silvaggi JM, Rhee J, Jäger S, et al. Suppression of reactive oxygen species and neurodegeneration by the PGC-1 
transcriptional coactivators. Cell. 2006;127:397-408. https://doi.org/10.1016/j. cell.2006.09.024.

37. Satish S, Philipose H, Rosales MAB, Saint-Geniez M. Pharmaceutical Induction of PGC-1 a Promotes Retinal Pigment Epithelial Cell Metabolism and Protects against Oxidative Damage. Oxid Med Cell Longev. 2018;2018:1-9. https://doi.org/10.1155/2018/9248640.

38. Hu Y, Duan M, Liang $S$, Wang Y, Feng Y. Senkyunolide I protects rat brain against focal cerebral ischemia-reperfusion injury by up-regulating $\mathrm{p}$-Erk $1 / 2$, Nrf2/HO-1 and inhibiting caspase 3. Brain Res. 2015;1605:39-48. https://doi. org/10.1016/j.brainres.2015.02.015.

39. Kanzaki H, Shinohara F, Kanako I, Yamaguchi Y, Fukaya S, Miyamoto Y, et al. Molecular regulatory mechanisms of osteoclastogenesis through cytoprotective enzymes. Redox Biol. 2016;8:186-91. https://doi.org/10.1016/j. redox.2016.01.006.

40. Hu H, Hao L, Tang C, Zhu Y, Jiang Q, Yao J. Activation of KGFR-Akt-mTORNrf2 signaling protects human retinal pigment epithelium cells from Ultraviolet. Biochem Biophys Res Commun. 2018;495:2171-7. https://doi.org/10. 1016/J.BBRC.2017.12.078

41. Felszeghy S, Viri J, Paterno JJ, Hyttinen JM, Koskela A, Chen M, et al. Loss of NRF-2 and PGC-1a genes leads to retinal pigment epithelium damage resembling dry age-related macular degeneration. Redox Biol. 2018;20:1-12. https://doi.org/10.1016/j.redox.2018.09.011

42. Huang S-Y, Chang S-F, Chau S-F, Chiu S-C. The Protective Effect of Hispidin against Hydrogen Peroxide-Induced Oxidative Stress in ARPE-19 Cells via Nrf2 Signaling Pathway. Biomolecules. 2019;9:380. https:/doi.org/10.3390/ biom9080380.

43. Hu $X$, Liang $Y$, Zhao $B$, Wang $Y$. Thymoquinone protects human retinal pigment epithelial cells against hydrogen peroxide induced oxidative stress and apoptosis. J Cell Biochem. 2019;120:4514-22. https://doi.org/10.1002/ jcb.27739.

44. Arumugam B, Palanisamy UD, Chua KH, Kuppusamy UR. Protective effect of myricetin derivatives from Syzygium malaccense against hydrogen peroxideinduced stress in ARPE-19 cells. Mol Vis. 2019;25:47-59 http://www.ncbi.nlm. nih.gov/pubmed/30820141. Accessed 17 Sep 2019.

45. Zhao H, Wang R, Ye M, Zhang L. Genipin protects against H2O2-induced oxidative damage in retinal pigment epithelial cells by promoting Nrf2 signaling. Int J Mol Med. 2018:936-44. https://doi.org/10.3892/ijmm.2018. 4027.

46. Wang Z, Hao Y, Wang Y, Liu J, Yuan X, Sun B, et al. Wheat alkylresorcinols protect human retinal pigment epithelial cells against $\mathrm{H}$ 2O2-induced oxidative damage through Akt-dependent Nrf2/HO-1 signaling. Food Funct. 2019;10:2797. https://doi.org/10.1039/c8fo02564a.

47. Wang $K$, Jiang $Y$, Wang W, Ma J, Chen M. Escin activates AKT-Nrf2 signaling to protect retinal pigment epithelium cells from oxidative stress. Biochem Biophys Res Commun. 2015;468:541-7. https://doi.org/10.1016/J.BBRC.2015. 10.117.

48. Muangnoi C, Sharif U, Ratnatilaka Na Bhuket P, Rojsitthisak P, Paraoan L. Protective Effects of Curcumin Ester Prodrug, Curcumin Diethyl Disuccinate against H2O2-Induced Oxidative Stress in Human Retinal Pigment Epithelial Cells: Potential Therapeutic Avenues for Age-Related Macular Degeneration. Int J Mol Sci. 2019;20:3367. https://doi.org/10.3390/ijms20133367.

49. Gasperi V, Sibilano M, Savini I, Catani MV. Niacin in the central nervous system: An update of biological aspects and clinical applications. Int J Mol Sci. 2019;20:1-26.

50. Liu D, Wang X, Kong L, Chen Z. Nicotinic Acid Regulates Glucose and Lipid Metabolism Through Lipidindependent Pathways. Curr Pharm Biotechnol. 2014;16:3-10.

51. Ruparelia N, Digby JE, Choudhury RP. Effects of niacin on atherosclerosis and vascular function. Curr Opin Cardiol. 2011;26:66-70. https://doi.org/10. 1097/HCO.0b013e3283410c16.

52. Sahebkar A. Effect of niacin on endothelial function: A systematic review and meta-analysis of randomized controlled trials. Vasc Med. 2014;19:54-66. https://doi.org/10.1177/1358863X13515766.

\section{Publisher's Note}

Springer Nature remains neutral with regard to jurisdictional claims in published maps and institutional affiliations.

Ready to submit your research? Choose BMC and benefit from:

- fast, convenient online submission

- thorough peer review by experienced researchers in your field

- rapid publication on acceptance

- support for research data, including large and complex data types

- gold Open Access which fosters wider collaboration and increased citations

- maximum visibility for your research: over $100 \mathrm{M}$ website views per year

At BMC, research is always in progress.

Learn more biomedcentral.com/submissions 